\title{
Geovo, E. (2018). El dios Jano: de lo fenoménico a lo probable. Criterios para la vida práctica de los pirrónicos y los neoacadémicos. Bogotá: Universidad Libre.
}

Camilo Andrés Ardila Arévalo ${ }^{1}$

Universidad Libre, Colombia

\footnotetext{
1 Abogado y filósofo de la Universidad Libre. MSc. International Political Theory de la Universidad de Edimburgo, miembro del semillero de investigación Méthexis de la Universidad Libre.

Correo electrónico: camiloa.ardilaa@unilibrebog.edu.co
} 
Autor: Eduardo Geovo Almanza (2018)

Editorial: Universidad Libre.

Año: 2018

Una de las reiteradas críticas al escepticismo filosófico radica en su presunta ineficacia para la vida práctica. Después de todo, los filósofos escépticos parecen estar condenados de antemano, en caso de ser consistentes con su postura epistemológica, a una constante indecisión frente a todo asunto que requiera tomar partido en uno u otro sentido, de modo que, tarde o temprano, caerían en una especie de inacción inútil (apraxia) o, en el peor de los casos, en la irreflexiva aceptación de las convenciones ya existentes. Esta acusación constituye precisamente la trama central que subyace al libro titulado El dios Jano: de lo fenoménico a lo probable. Criterios para la vida práctica de los pirrónicos y los neoacadémicos. En este sentido, el texto del profesor Geovo reivindica el valor preventivo del escepticismo frente a las tendencias propias del dogmatismo y el fanatismo, al tiempo que explora las posibilidades teóricas del constante cuestionamiento escéptico ante la pregunta por el accionar de los seres humanos.

Lo anterior, en contraposición a buena parte de las discusiones contemporáneas alrededor del escepticismo antiguo, que parecieran dejar de lado su dimensión ética y política, para enfocarse en las cuestiones estrictamente epistemológicas. Como bien lo sugiere el autor, el menor espacio discursivo que normalmente se brinda a la perspectiva ética y política del escepticismo antiguo, resulta desconcertante si se tiene en cuenta que las escuelas helenísticas han estado tradicionalmente relacionadas con un propósito de orden práctico y no meramente teórico. Así pues, la obra del profesor Geovo tiene la virtud de no solamente rescatar un ángulo subestimado del escepticismo antiguo, sino que también hace uso de la lucidez necesaria para poner sobre la mesa de discusión una de las paradojas más interesantes del escepticismo en general: el hecho de ser una postura filosófica tradicionalmente vinculada a los más encumbrados debates epistemológicos, aunque, al mismo tiempo, haber surgido en el contexto de una finalidad primordialmente práctica relativa a la imperturbabilidad.

Ahora bien, la discusión acerca del valor práctico y potencialmente político del escepticismo antiguo, como el nombre de la obra lo señala, se ambienta en 
el contexto de dos corrientes específicas: los pirrónicos y los neoacadémicos. Esto significa, como resulta esperable, que el desarrollo del texto se vale también de un importante trabajo en términos doxográficos ante la inevitable circunstancia de que, en casos como el de Pirrón, no siempre se conserven textos directamente atribuidos a los pensadores en cuestión. De ahí que exista la necesidad de recurrir a los comentarios u opiniones de terceros, como Diógenes Laercio. Este, precisamente, es otro aspecto destacable del esfuerzo académico del autor de El dios Jano, ya que su obra logra reconstruir el problema filosófico del escepticismo pirrónico y neoacadémico a través de una sistematización y crítica cuidadosa de las fuentes primarias, sin dejar a un lado una juiciosa ponderación del valor histórico y filosófico del material doxográfico para la discusión.

Desde el punto de vista estructural, la presentación del problema filosófico al interior del libro se da a través de tres capítulos que parecen abrirse paso de forma fluida desde lo teórico hacia lo práctico. De un lado, el autor aborda los planteamientos centrales del escepticismo antiguo, cuyo carácter eminentemente epistemológico permite plantear el problema del criterio de verdad y la posible existencia de tal criterio para la vida práctica; de otro lado, el texto elabora una síntesis de las diferentes expresiones argumentativas que adoptan los planteamientos escépticos entre los pirrónicos y los neoacadémicos, al hacer un énfasis en los argumentos de orden purgativo de aquellos y las estrategias argumentativas de estos; con lo que se adentra en el valor que estos planteamientos y estrategias argumentativas podrían tener para la vida práctica y eventualmente para el razonamiento político. En este orden de ideas, puede decirse que el texto, siguiendo el derrotero que sugiere su título, aborda la reflexión pirrónica y neoacadémica desde lo fenoménico hacia lo probable; mejor dicho, partiendo de la constatación epistemológica de las limitaciones del conocimiento humano para los pirrónicos y concluyendo en la naturaleza meramente probable de los juicios prácticos para los neoacadémicos.

Puede decirse, por último, que el libro permite entrever una conclusión general: la mayor inclinación del escepticismo neoacadémico hacia la vida práctica por medio de la noción de lo probable. Esto supone que -si bien hubo una corriente del escepticismo antiguo que estuvo más enfocada en la búsqueda de la autosuficiencia e imperturbabilidad en términos personales y casi apolíticos- es posible concebir una noción de escepticismo filosófico 
entre los neoacadémicos que, sin caer en el dogmatismo y el fanatismo, haga uso de la noción de lo probable para dar cuenta de los juicios prácticos $\mathrm{y}$, eventualmente, de los razonamientos políticos. Cualquiera que sea el caso, el libro del profesor Geovo resalta de manera erudita el valor del escepticismo como una disposición del espíritu hacia el cuestionamiento constante en términos filosóficos, de modo que, incluso por esa sola razón, se hace imperativa la lectura de su obra. 